\title{
ДЕРМАТОМИОЗИТ: КЛИНИКА И ДИАГНОСТИКА
}

'Бадалова С.Т., ${ }^{1}$ Бадалова У.Т., ${ }^{1}$ Миралиева М.С., ${ }^{1}$ Садигов М. С., ${ }^{1}$ Мусаева Г.А, ${ }^{1}$ Сафарова С.А., ${ }^{1}$ Рамазанова Г.К., ${ }^{1}$ Ахундова А.Г., ${ }^{1}$ Оруджиев М.Я., ${ }^{2}$ Салаев К.А., ${ }^{1}$ Гасанбекова Е.Э. ${ }^{1}$ Детская неврологическая больнииа г. Баку; ${ }^{2}$ Кафедра неврологии и медицинской генетики Аз. Мед. Университета, г. Баку

Диффузные заболевания соединительной ткани (ДЗСТ) - группа заболеваний, характеризующихся системным иммуновоспалительным поражением соединительной ткани и ее производных. ДЗСТ объединяют достаточно большое число заболеваний, из которых основными являются системная красная волчанка, системная склеродермия, дерматомиозит. В настоящее время доказано, что при ДЗСТ происходят глубокие нарушения иммунного гомеостаза, выражающиеся в развитии аутоиммунных процессов, т.е. реакции иммунной системы, сопровождающиеся появлением антител или сенсибилизированных лимфоцитов, направленных против антигенов собственного организма - аутоантигенов.

Дерматомиозит (ДМ) - системное воспалительное заболевание скелетной, гладкой мускулатуры и кожи. Реже отмечается вовлечение внутренних органов. Сущность заболевания - это прогрессирующе тяжелый некротический миозит с преимущественным поражением проксимальных мышц. По мере прогрессирования мышечная ткань атрофируется и замещается фиброзной. Болезни подвержены и дети и старшие, но обычно дети до 15 лет; женщины болеют в 2 раза чаще.

Различают две формы ДМ - идиопатический и вторичный опухолевой. Этиология идиопатического неизвестна, однако известны факторы, способствующие выявлению заболевания: инсоляция, охлаждение, инфекция (OP3, грипп, ангина), гормональная перестройка (климакс, беременность, роды), эмоциональный стресс, физическая травма, хирургическое вмешатеьство, сенсибилизация лекарственными препаратами, вакцинация, контакт с эпоксидными смолами, физиотерапевтические процедуры.

В основе патогенеза лежит выработка антител к скелетным мышцам.

Клиническая картина включает следую- щие основные синдромы:

1) мышечный (миозит, мышечные атрофии, кальцификация)

2) кожный (эритема, отек кожи, дерматит, пигментация и депигментация, телеангиэктазии, гиперкератоз, крапивница)

3) суставной - артралгии, поражение периартикулярной ткани

4) висцеральные - миокардит, кардиосклероз, пневмонит, аспирационные пневмонии, пневмофиброз, «миоглобулинурическая» почка, полинейропатии.

Выделяют следующие периоды:

1 период (начальный) - от нескольких дней до 1 месяца и более - проявляется только мышечными и (или) кожными признаками

2 период (манифестный) - определяется развернутая картина болезни

3 период - терминальный, проявляется дистрофическими изменениями внутренних органов.

На первом этапе наиболее характерны жалобы, обусловленные мышечными поражениями: больные отмечают слабость, не могут самостоятельно сесть или встать, им трудно подниматься по лестнице, нередки боли в мышцах. Мышечная слабость и болезненность локализуется симметрично в проксимальных отделах конечностей, а также в спине и шее. При поражении глоточных мышц наблюдается поперхивание, при глотании - жидкая пища выливается через нос. Носовой оттенок голоса, охриплость обусловлены поражением мышц гортани. Поражение кожи - больные отмечают стойкое изменение ее окраски в местах, подверженных действию солнца, а также на наружных поверхностях бедер и голеней. Характерно появление параорбитального отека лилового цвета (симптом очков). При поражении слизистых оболочек - больные жалуются на сухость, жжение в глазах, отсутствие слез. 
Вовлечение в патологический процесс различных органов проявляется симптомами, свойственными миокардиту, кардиосклерозу, пневмониту, гломерулонефриту, полиневриту, артриту и пр.

На втором этапе обращает внимание симметричное поражение мышц: плотные на ощупь, увеличены в объеме, болезнены при пальпации. При поражении мимической мускулатуры - отмечается некоторая маскообразность лица. В дальнейшем - атрофия мышц, особенно в плечевом поясе. Поражаются также диафрагма и дыхательные мышцы. При пальпации можно обнаружить локальные уплотнения - кальцинаты, которые располагаются в подкожной жировой клетчатке.

Поражение кожи - в виде отека, эритемы особенно над суставами с микронекрозами в виде темных точек, капиляриты, петехиальные высыпания, телеангиэктазии. Эритема отличается большой стойкостью, синюшным отттенком, сопровождается зудом и шелушением. Давольно часто отмечается с-м Рейно.

Поражение сердца - глухость тонов, увеличение его размеров, тахикардия, нарушение ритма в виде экстрасистолии.

Поражение легких - пневмонит.

Поражение пищеварительного тракта дисфагия. Иногда отмечается умеренное увеличение печени, селезенки с увеличением лимфатических узлов.

Неврологическая симптоматика проявляется изменениями чувствительности: гиперстезией переферического или корешкового характера, гипералгезией, парастезией и арефлексией.

Анализы: повышение СОЭ, повышение содержания фибриногена, СРБ, появление в не высоком титре ревматоидного фактора, увеличение содержания антител к нуклеопротеиду и растворимым ядерным антигенам. Распространенность поражения мышц характеризуется рядом биохимических показателей. Повышаются уровень сывороточных ферментов (АСТ, АЛТ, КФК, альдолаза), индекс креатин/ креатинин за счет появления в моче креатина при снижении креатинурии. При значительном пораже- нии мышц может наблюдаться миоглобинурия. Для ДМ опухолевого происхождения характерно увеличение альфа-один-липопротеиновой фракции сыворотки крови.

Существенную помощь в диагностике поражения мышц оказывает электромиография, биопсия кожи и мышц.

Лечение: глюкокортикоиды 1 мг\кг\сут. Преднизолон принимают 2-3 мес. Если преднизолон не дает эффекта используют цитостатики - азотиоприн (имуран). Цитостатики применяют 2-6 мес. Аминохинолиновые препараты: хингамин (делагил), плаквинил - используют при хроническом течении болезни и при снижении дозы преднизолона или цитостатиков дляснижения риска возможного обострения.

В Детскую неврологическую больницу обратились родители девочки 7 лет с жалобами на потерю способности к самостоятельному передвижению, выраженный болевой синдром в туловище и конечностях, изменение голоса, гипергидроз, гипертрихоз преимущественно в конечностях. Болеет около 1,5 мес. Заболевание началось с повышения температуры, отеком коленных суставов.

Девочка от первой беременности. Берменность и роды со слов матери протекали без особенностей. Вес при рождении 3200гр. Раннее психомоторное и речевое развитие соответствовало возрасту.

При осмотре: кожа на лице гиперемирована, отмечается периорбитальный отек и покраснение век, уплотнение кожи лица в области носо-губного треугольника - из-за этого выражение лица гипомимичное. Кожа на конечностях влажная на ощупь, отмечается гипертрихоз преимуществено в области коленных суставов.

Речь гнусавая. Поперхивается при приеме жидкой пищи.

В двигательной сфере: мышечная сила в конечностях снижена. Сухожильные рефлексы не вызываются. Отмечается болезненность мышц при пальпации и при выполнении активных движений. Девочка эмоционально лябильна. Реакция на окружающее сохранена. Менингеальных знаков нет. 
Девочка была осмотрена педиатром: на коже внутренней поверхности плеча отмечается расширение капиляров кожи и гиперпигментация вследствие сдавления этих участков при попытке перевести девочку в вертикальное положение. Аускультативно: со стороны сердца - глухость тонов, тахикардия. В легких - жесткое дыхание.

Анализы: В крови отмечалось повышение СОЭ, СРБ, лейкоцитоз, Повышение уровня АЛТ, АСТ. УЗИ внутренних органов - увеличение селезенки.
Учитавая данные клиники и вспомогательных методов лечения больной был выставлен диагноз дерматомиозит и болная для дальнейшего лечения и наблюдения была переведена в профильное учреждение.

Таким образом, полисистемность поражения с вовлечением изменений со стороны кожи, мышц, внутренних органов, нервной системы, соответствующие данные дополнительных методов исследования делают необходимым в первую очередь исключить возможность наличия системного заболевания.

\title{
XULASə
}

\section{DERMATOMIOZIT: KLINIIKA Və DİAQNOSTIKA}

\author{
${ }^{1}$ Bədəlova S.T., ${ }^{2}$ Bədəlova U.T., ${ }^{1}$ Mirəliyeva M.S., ${ }^{1}$ Sadiqov M.S., ${ }^{1}$ Musayeva Q.A., ${ }^{1}$ Səfərova S.A., \\ ${ }^{1}$ Ramazanova Q.K., ${ }^{1}$ Axundova A.Q., ${ }^{1}$ Orucov M.Y., ${ }^{2}$ Salayev K.A., ${ }^{1}$ Həsənbəyova Y.E. \\ ${ }^{1}$ Uşaq nevroloji xəstoxanasi, Bakl; \\ ${ }^{2} A T U$-nun nevrologiya vo tibbi genetika kafedrası, Bakı
}

Birləşdirici toxumanin qarışmış xəstəlikləri (BTQX) - birləşdirici toxumanın və onun törəmələrinin zədələnməsi ilə səciyyələnən xəstəliklər qrupudur. Bu qrupa çox xəstəliklər aiddir.Bu xəstəliklərdən biri də dermatomiozitdir. Dermatomiozit - skelet, saya əzələlərin və dərinin sistem iltihab xəstəliyidir. Bu xəstəlikdə daxili üzvlərin zədələnməsi daha az qeyd olunur. Biz dermatomioziti olan xəstənin xəstəlik tarixçəsini təqdim edirik. Müayinə vaxti xəstədə dəri, əzələ, daxili üzvlər, sinir sistemı tərəfindən dəyişiklər aşkar olunub. Polisistem zədələnmələrə və instrumental, laborator muayinələrin nəticəsinə əsasən dermatomiozit diagnozu qoyulmuşdur.

\section{SUMMARY}

\section{DERMATOMYOSITIS: CLINIC AND DİAGNOSTIC}

\author{
${ }^{1}$ Badalova S.T., ${ }^{2}$ Badalova U.T., ${ }^{1}$ Miraliyeva M.S., ${ }^{\text {Sadigov M.S., }}{ }^{1}$ Musayeva G.A., ${ }^{1}$ Safarova S.A., \\ ${ }^{1}$ Ramazanova G.K., ${ }^{1}$ Akhundova A.G., ${ }^{1}$ Orujov M.Y., ${ }^{2}$ Salayev K.A., ${ }^{1}$ Hasanbekova Y.E. \\ ${ }^{1}$ Child Neurology Hospital, Baku; \\ ${ }^{2}$ The Department of Neurology and genetics of Azerbaijan Medical University, Baku
}

Mixed connective tissue diseases are a group of disease of connective tissue characterized with impairment of connective tissue and its derivates. Dermatomyositis is one of the several different disorders represented this group. Dermatomyositis is a systemic inflammatory disease of the skeleton, smooth muscles and skin. The impairment of internal organs is less frequent in dermatomyositis. In this paper, the case of dermatomyositis is presented. During examination, pathological changes in skin, muscles, internal organs and nervous system were discovered. The diagnosis of dermatomyositis was based on clinical multisystemic impairments and results of instrumental and laboratory tests. 